\title{
TABOO AVOIDANCES IN KARO LANGUAGE
}

\author{
Jumat Barus \\ Institut Agama Islam Negeri Lhokseumawe, Aceh, Indonesia \\ E-mail: jumatbarus@iainlhokseumawe.ac.id
}

Received: 19 April 2020

Accepted: 02 May 2020

\begin{abstract}
Civilized society like Karo knows taboo culture and how to avoid it well, so that they can be avoided from social conflict and can live peacefully. However, taboo in language and the way to avoid them are considered increasingly scarce as globalization develops among the current millennial generation. As an effort to provide an understanding about the matter concerned towards future generations, this study describes various ways of avoiding the three types of taboo in Karo: taboo in kinship, i.e. among bengkila and permain, turangku and turangku, and mami and kela; contextspecific taboos, i.e. words derived from non-taboo words, and words related to social and physical defects; and general taboos, i.e. swearing and unmentionable words. This research was conducted using descriptive qualitative with ethnographic method. The data were obtained from the key informants who were from indigenous people of Tanah Karo Regency. It is found that taboos in kinship can be avoided by strategy of third-person intermediary, strategy of metaphor through object, and strategy of using the word nina. Context-specific taboo and general taboo can be avoided by various forms of euphemism. However, taboo of swearing type does not have form of refinement because of its purpose and function as emotive expression.
\end{abstract}

Keywords: taboo, euphemism, kinship, context-specific

\section{Introduction}

Every cultured tribe certainly has a cultural product which is named taboo. It exists in all cultures, generally related to sexuality, supernatural, excretion, death, and various aspects of social life. It is generally considered sacred, should not be touched or spoken, since it is considered as a prohibition (Danesi, 2004: 128). While, Allan and Burridge (2006: 27-33) state that taboos are more than prohibitions and avoidance in tradition. He further says that taboo normally arises from social restrictions on individual behavior that can lead to inconvenience and danger.

Taboo in Karo language, according to Barus et.al. (2018), is mainly classified into three categories, they are: kinship, context-specific, and general. The kinship taboo is generally known as rebu, that is a taboo term refering to communication activity that violates cultural rules when it is carried out directly in a kinship among bengkila 'father-in-law' (husband's father) with permain 'daughter-in-law' (son's wife), turangku 'husband's sister's husband' with turangku 'wife's brother's wife', and mami 'mother-in-law' (wife's mother) with keila 'son-inlaw' (daughter's husband). In addition, they are also prohibited to sit face to face and side by side without intermediaries. Rebu, according to Sembiring (2013) starts when Karonese get 
married. After the wedding there is a ceremony called the mukul marriage rite, held in the groom's parents' house. This is when the bride and groom have dinner from the same plate and the menu has been determined by the groom's parents. Further, Barus et.al. explained that the context-specific taboo includes words that have no taboo meaning lexically, but their use in certain contexts make them taboo. This category is further divided into two subcategories: non-taboo words and words related to social and physical defects. The general taboo consists of swearing and unmentionable words. These context-specific taboo and general taboo are known as kemali or sikemali in Karo language.

The verbal and nonverbal expressions that are considered taboo by the Karo society can be avoided in various ways according to their respective contexts or words, however the swearing which is one of the sub classifications of general taboo has no form of avoidance for its purpose and function as an emotive expression that reflects, or seems to reflect the feelings or behaviours of the speaker.

\section{Theoretical Framework}

This study is a small piece of interdisciplinary science named Linguistic Anthropology, that is "the study of speech and language within the context of anthropology" (Hymes, 1963: 277). Based on these, Duranti (1997: 2-3) explains that Linguistic Anthropology is a study of language as a cultural resource and speaking as a cultural practice. While, Foley (1997: 3) uses the term anthropological linguistics and calls this term a sub-field of linguistics which is concerned with the place of language in its wider social and cultural context, its role in forging and sustaining cultural practices and social structures. This study views language through the prism of the core anthropological concept, culture, and as such, seeks to uncover the meaning behind the use, misuse or non-use of language, its different forms, registers and styles. It is an interpretative discipline peeling away at language to find cultural understandings.

Regarding the taboo avoidance strategy, this study uses the concept of euphemism as explained by Allan dan Burridge (2006: 32). Euphemisms are words or phrases used as an alternative to a dispreferred expression. They avoid possible loss of face by the speaker, and also the hearer or some third party. Wardhaugh (2010: 249) explains that euphemism is to avoid mentioning certain matters directly. He further explains that language is also used to avoid saying certain things as well as to express them. Certain things are not said, not because they cannot be, but because 'people don't talk about those things'; or, if those things are talked about, they are talked about in very roundabout ways. Related its forms, Allan and Burridge (2006: 128) explains that euphemisms are created by circumlocution, phonological modification, extending the meaning of a near-synonym (thus reintroducing rarely used words into the basic vocabulary), borrowing from another language, or even by coining a new word.

\section{Research Method}

The research applied qualitative approach with ethnographic methods. By applying such approach and method, the reasearch achieved better results, for it was considered a very appropriate method in investigating accurate information from local people about various strategies they used in avoiding the taboos. In this case, the researcher used the ethnographic method initiated by Spradley (1979), which was by following the twelve steps of developmental research sequence. It was conducted in Tanah Karo Regency, North Sumatra Province, Indonesia, specifically in Berastagi district, Kabanjahe district, Tigapanah district, Barus Jahe district, and Simpang Empat district. The data were obtained from 9 indigenous 
informants who understood the culture and language of Karo very well, so that the researcher had strong confidence to the data obtained.

\section{Results and Discussion}

\subsection{Avoiding Kinship Taboo}

Avoiding taboos in communication among three types of relationships, namely among bengkila with permain, turangku with turangku, and mami with keila can be done using three strategies. In communication, people who are included in these kinds of relationship must maintain a distance between one another (should not be too close) and it is highly recommended not to look at each other's interlocutors. Besides, such conversations can be carried out under compulsion and conveyed only very important things. The three strategies are as follows:

\section{a) Strategy of third-person intermediary}

Communication among two people who are prohibited from communicating directly can be avoided through the intermediary of others as a media to convey messages and as a messenger to the actual interlocutor. Communication as such can be described as follows:

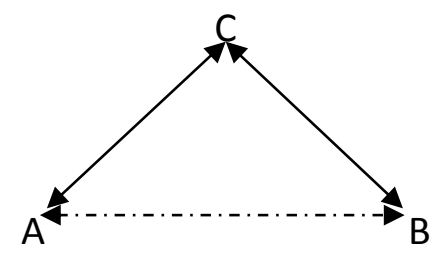

Figure 1: Strategy of third-person intermediary

The figure above is the flow of communication among the member of kinship taboo " $A$ " and " $B$ ". As a result of the prohibition in their relationship, both of them need other person " $C$ " as their intermediary. $C$ as a third person is needed and functions as a recipient and messenger of messages from $A$ to $B$ and vice versa. When $A$ wants to convey or ask something to $B$ and vice versa, they must do that through $C$. Communication like this can be seen in the following example:

(1) Bengkila $(A)$ : O Jenni, sungkun sitik permain ena kuja atena.

'O Jenni, please ask permain where she is going'.

$\begin{array}{ll}\text { Jenni }(C): & \text { Kuja ateindu e Eida? } \\ & \text { 'Where are you going, Eida (sister in law)?' } \\ \text { Permain (B) : } & \begin{array}{l}\text { Ku tiga Jenni, kai kin? } \\ \text { 'To supermarket Jenni, what happen?' }\end{array} \\ \text { Jenni }(C): & \begin{array}{l}\text { Ku tiga nina, } P a . \\ \text { 'She's going to supermarket, } P a \text { (father)!' }\end{array} \\ \text { Bengkila }(A): \begin{array}{l}\text { Suruh tukurna sitik isapku da. } \\ \text { 'Ask her to buy cigarettes for me, okay. }\end{array}\end{array}$

In the short conversation above, the people who actually need communication are Bengkila and Permain, but because they are considered the members of taboo, they cannot speak directly, so they must convey their expression through a third person as their intermediary, namely Jenni (a daughter of Bengkila). Bengkila asked Permain through Jenni, 
then she passed on his question to Permain, and Permain answered the question through Jenni, then Jenni passed her answer on to Bengkila, and so on. Communication like this also applies to two other members of taboo relationships, namely among Turangku and Turangku, and Mami and Keila. By using this strategy, communications among those members of kinship taboo can run well and not violating the norms of customs in Karo society.

\section{b) Strategy of Metaphor through Object}

Communication as in the previous strategy cannot always be done, because there are times when there is no third person who can be used as an intermediary. In emergencies and urgently needed to communicate, the taboo participants can use strategy of metaphor through objects, as it is in the previous strategy, by representing any object existing around them. In this case, it is considered as if the object can receive and convey messages as done by the third person in the previous strategy. When A wants to convey or ask something to $B$, A conveys to the object concerned about what he/she wants to convey or ask, and as if the object hears it and then forward it to $B$, the interlocutor, and vice versa. However, this type of communication needs both of the taboo participants to hear each other about what they are saying to the object.

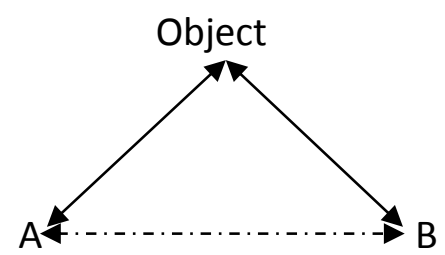

Figure 2: Strategy of Metaphor through Object

This taboo avoidance strategy can be illustrated in the short conversation among Turangku and Turangku, as follows:

(2) Turangku: Sungkun sitik turangku eina, tah tehna kuja bapa Badi ndai, pintu.

'Please ask Turangku, does she know where Badi's father went, pintu ('door').

Turangku: O pintu, kataken man turangku eina, la kueteh kuja bapa Badi ndai, tapi kuakap pak kedai ia, pintu 'O pintu, tell Turangku, I don't know where Badi's father went, but I think he went to the coffee shop, pintu.'

Turangku: O.., bujur ningen man turangku eina, pintu.

(A) 'O.., please say thanks to Turangku, pintu.'

The conversation above can be done by the members of taboo in a very urgent situation, because Turangku (A) does not find other people in or around turangku's house (B) as an intermediary, while Turangku (A) have to convey something important to Turangku (B). In such circumstances, both Turangku (A) and Turangku (B) treat pintu 'door' as a projection media to reflect their conversation to their interlocutor. When conducting this communication, it is also very important to be obeyed that the taboo participants must not look each other as much as they can. 


\section{c) Strategy of using word 'nina' ('said x')}

Besides using the previous strategies, the members of taboo can use the word "nina" (' $x$ said'). Karo society call the strategy "ernina". In conducting conversation, the two members of taboo involved in a conversation use the word nina in every sentence they convey. Uniquely in using the word nina, each directs his or her utterances to the interlocutor, so as if it is not he himself says it, but the interlocutor. Besides, the word nina is also considered as a means of conveying or delivering messages to the interlocutor. This can be showed as follows:

$$
\mathrm{A}(\mathrm{B}) \leftarrow-n i n t \rightarrow(\mathrm{A}) \mathrm{B}
$$

Figure 3: Strategy of Using the Word nina ('said $x^{\prime}$ )

The figure shows the role and flow of the usage of the word nina to legalize communication among taboo members in Karo language. It is clear that in carrying out the conversation, A uses nina as if he is B and vice versa, $B$ uses nina as if she is A. For more details, the usage of this strategy can be seen in the following short conversation among Turangku $(A)$ and Turangku (B):

(3) Turangku: Kuja idahndu silihndu ndai? Nina Turangku.

(A) 'Where does your brother-in-law go? said Turangku?'

Turangku: E, la kueteh, nina turangku, ku jah kuakap, nina Turangku.

(B) 'I don't know, said Turangku, maybe going there, said Turangku.'

Turangku: O... bujur, nina turangku.

(A) 'O...thank you, said Turangku.'

In the short conversation above, Turangku (A), in delivering his statements and questions, always uses the word nina turangku ('said turangku'), as if he is not the person speaking, but turangku (B). It is the same with turangku (B), when giving statements and questions, Turangku (B) also uses nina turangku ('said turangku'), as if she is not the one speaking but turangku (A). This strategy is applied as an effort to avoid direct conversation in kinship taboo in Karo language.

\subsection{Avoiding Context-Specific Taboo}

Taboo of this kind is different from those in the previous part, that the context-specific taboo is in the form of words or phrases that basically have ordinary meaning, but they can mean taboo in certain contexts. Some words or phrases that belong to this group can be avoided and some cannot be. Words or phrases that cannot be avoided are all non-taboo words used in curses or swearing. The use of non-taboo words in the form of names of organs of body (such as babah 'mouth', mata 'eyes', takal 'head'), and names of animals (such as babi 'pig', biang 'dog', kerbou 'buffalo', bengkala 'ape') is in profanity, whether it is swearing, insulting, cursing, blaspheming, etc., and this cannot be avoided because of the context and purpose. It is understandable that someone who swears is a result of his high tempramental soul, so he curses, blasphemes, and swears, and so on with the aim to give bad effect to the interlocutor. That is the reason why non-taboo words of this group cannot be avoided, in other words, swearing can be avoided only by not mentioning such words. It can also be said that expressions which avoid taboo are not part of swearing. 
Unlike some words that derive from non-taboo, the use of names of wild animals (such as nipe 'snake', gajah 'elephant', arimo 'tiger') and supernatural beings (begu) in certain places, which are usually not used in swearing, can be avoided by language refinement or euphemism. To avoid the use of taboo language, generally, these four words are replaced by specific appelation nini 'grandmother' or nini si njaga kerangen 'grandmother the jungle guardian'. The use of the word nini is intended as a tribute, because nini in Karo language is the parent of father, and is a figure that must be fully respected. The guardian of jungle is used as a tribute because the wild animal is positioned as a guardian entity that has extraordinary powers in the forest area. This title is considered as a tribute, and is believed by the tribute and praise to the beast, and by this the karo community can avoid the anger and fury of these creatures.

Specifically, the mention of nipe 'snake' is usually replaced by the word waren 'creeping grass' and si gedang gendit 'the long belt'. Both of the euphemisms are the form of refinement of their original name which is considered taboo. Nipe creeps like grass that creeps in forest, so that this reptile is called waren 'creeping grass'. By using this word, society is considered to understand what it is referring to, and by using it, it will not provoke the animal's anger. While, si gedang gendit is used to refer to snake because of its physical shape which is similar to a belt which in Karo is named gendit.

The wild animal arimo 'tiger', in addition to the name of nini si njaga kerangen 'grandmother the jungle guardian', the name of arimo is usually refined with si belang awak. Si belang means 'the striped color' and awak means 'body'. Altogether this phrase means 'striped colored animal'. This phrase is used as a form of euphemism of arimo, because of its wide body shape and its yellow-black fur. With the phrase of si belang awak, the Karo people understand about the entity referred to and is considered to have moved away from the taboo so as to avoid possible dangers.

Gajah 'elephant' is one of the wild animals that are feared to mention its name in Karo, especially in jungle and farming areas. To avoid the danger that is believed to be caused by the animal's anger, the Karo people use another name as a form of euphemism that refers to an animal called an elephant. As the form of refinement, Karo society usually called it datuk 'ancestor' (a person who is glorified). By using the word datuk, the Karo community believes that these wild animals will feel respected so that they will not be angry and damage the citizen's plants.

Likewise with the so-called begu 'ghost', the name of this supernatural entity also has a form of euphemism to avoid undesired things. The form of euphemism that is often used as a refinement to the spirits (begu) is also nini. Begu in the beliefs of ancient Karo people is the soul or spirit of dead people. The deceased person deserves to be called the one who has preceeded, and in the family tree of the former or the oldest is nini, so the form of euphemism for this entity is called nini. Begu in Karo language is a disturber entity, therefore this creature must be respected or honoured, by using a name that makes him feel respected. With this name 'nini', those spirits or begu will not do undesirable things, such as causeing sickness and fear.

As creatures, humans have their strengths and weaknesses. Basically, humans will feel happy when others greet him or express their strengths or good sides, and vice versa, they will feel hurt when others express or greet him with the weaknesses or bad sides. Therefore, greeting someone by showing his weaknesses is considered taboo and has bad ethics towards fellow human beings. That is why, this must be avoided through refinement or euphemism. 
In Karo language, mental illnesses such as mehado 'crazy' and tabun 'epilepsy' have another form which is considered more polite, namely by paraphrasing techniques. Mehado and tabun can be refined with the phrase la seh-sehsa kal ukurna, lit sakitna, la bagi kita e kal oratna 'having mental disorder'. All forms of euphemism lead to the lack of normal systems and ways of thinking.

Physical disease named gadam 'leprosy' also has a form of avoidance. Its euphemism form is the phrase pinakit lau simou-mou 'desease of lau simou-mou'. Lau Simou-mou is a place in Kabanjahe where there is a hospital for lepers. The hospital is a place for people who have leprosy, a very scary disease and believed very difficult to be cured in ancient times. As the existence and function of the hospital have been widely known by Karo community as a place to cure such disease, finally this makes the community accustomed to call it by pinakit lau simou-mou. These also happen to physical deseases as pentang 'blind', and pasek 'deaf'. The word pentang can be refined by paraphrase la erpengidah/lanai erpengidah 'unable to see' or 'blind', whereas pasek 'deaf' and can be avoided with paraphrasing of la erpemegi 'unable to hear'.

Words related to death, namely mate 'die' is also considered taboo. In Karo language, the word mate has several forms of euphemisms, all of which are paraphrased. The paraphrase is used according to the circumstances, but in general the use of the word mate is said enggo idilo Dibata 'has been called by God'. Enggo idilo Dibata can be used in every circumstance. Enggo lawes 'already left' is specifically used when informing the death person who die due to illness. More specifically, if the deceased is someone who already has grandchildren, old age or commonly called cawir metua. Dying in such condition, can be called as enggo metua 'already old'. In other words, this is not commonly mentioned when someone informs the death of a young child. Whereas, in the context of traditional ceremony of death, mate it is commonly expressed with the phrase enggo idilo Dibata 'has been called by God', enggo lawes ku ingan si rasa lalap 'has gone to eternal place', enggo leben ngeiluk nandangi kita 'has preceeded us', enggo ngadap man Dibata 'have faced God' However, all forms of language euphemisms about death can be represented by the phrase enggo idilo Dibata. This phrase is commonly used in all conditions. Taboo verbal expressions related to murder, namely the word bunuh 'kill', can be avoided by using the word for buat kesah 'take a breath'. For example, a taboo expression related to murder, bunuh 'kill' can be avoided by buat kesah 'take a breath'. For example: Enggo bunuhna preman ah ndai 'he killed the gangster' can be avoided by enggo buatna kesah preman ah ndai 'he has taken the gangster's breath'.

\subsection{Avoiding General Taboo}

Some of taboo words that are classified as general taboo can be avoided, but some others cannot, except by leaving them. All the taboo words in swearing, namely skatology (taim!, ngengekmu! 'Your shit!' and patatmu/ikurmu! 'Your ass!'); sex organs (natum! 'your dick!', teli amem 'your mother's pussy!', and pepekmu! 'your cunt!'); sexual activities (entek/entek-entek 'getting fuck'); mother (family) (amem! 'your mother!' and bapam! 'your father!' ); ancestors (ninim! 'your grandmother!', and ninimu bulangmu! 'your grandfather!'); animals (babi 'pigs', biang 'dogs', bengkala 'monkeys/apes', and kerbo 'buffalo'); death (mate/tes 'dead', bunuh 'kill', geleh 'cut', takil 'chop', tebak 'stabbed', munggil 'dead', and ndelis 'suicide'); disease (mehado/adon 'crazy', pentang 'blind', and pinangko 'thief'); and prostitution (lonte 'bitches'), cannot be avoided by refinement or euphemism.

The group does not have better forms and ways to avoid the taboo because of its unique context, method, and purpose. It is understandable that someone who does a 
swearing is in a high emotional state due to things or treatments that are not in accordance with his wishes. These profanity words or phrases are spoken in a harsh and abusive manner, and with glances and sharp eyes towards the interlocutors. The words chosen and the way conveyed in such a way are considered to be able to vent their deep emotion and at the same time have an adverse effect on the interlocutor. This is why it has no forms of language refinement or euphemism. In other words, swearing whose words are replaced with finer forms, delivered with a low tone and fainter eyes, make this communication no longer considered swearing.

In contrast to swearings, taboo groups which cannot be mentioned can be avoided by their respective forms of euphemism. This is due to the context of its usage only in the context of ordinary conversation. Sub group of dirty words are divided into sex organs, sexual activity, bodily impurities, and disposal of bodily contaminants. All of these types have finer words as the avoidance of the taboo.

Male sex organ natu 'dick' can be refined by the word manuk 'chicken', piduk 'bird' and Dibata 'god'. Karo people use manuk and piduk to represent male genitals due to their shared characteristics. Physically, the male sex organ natu has fur, and in the experience of Karo societies, hairy animals that are widely known by the society are manuk and piduk. Unlike the case with these two forms of euphemism, Dibata 'God' is used to refine the word natu, because it is considered to have little in common, namely as a creator. Basically God does not have similarities in His substance, nature, or deeds. However, the Karo community regards the male genital as the "creator" and puts the fetus in the womb of a mother. This makes the Karo people use the word Dibata as a subtle form of the word natu.

Part of male genitals that are included in the taboo is naru-naruh 'testicles'. Although frequency of the usage of the word naruh-naruh is less frequent than the other organs. This word is also considered taboo in the Karo language. To avoid using this word of taboo, Karo people use the phrase baban-baban dilaki "male's luggage". The phrase is due to its existence which hangs on the male genitalia, as if it were a luggage, so that it is likened to a male's luggage.

The female sex organ teli/pepek 'vagina' is a very prohibited thing to say in Karo. To avoid this taboo, the Karo language uses juma 'fields', and sabah 'rice fields', and sometimes using lesung '=thing used to pound rice into flour'. Juma and sabah are areas where farmers place seeds to grow, while lesung is something used to put rice to pound using pestle. From its function, the three words have the same function which is the same as a place to put things. This has been considered the same function as the sex organ teli/pepek which is a place where men put their seeds into their women's wombs which will later develop into fetuses. The similarity of functions becomes a reason why Karo people use juma, sabah, and lesung as euphemisms for female sex organs.

In a woman's body, there are also other organs that are considered taboo to be mentioned. The organ is nonon/nenen 'breast'. To avoid mentioning the name of this organ, the Karo people use the word poula 'roomie' as its euphemism. In general, poula tastes sweet and is beneficial for health. Likewise, milk produced by or coming through the female organs nonon/nenen, becomes the main drink and source of energy for a baby. The similarity of these characteristics is used as a reason for the Karo people to refine the word nonon/nenen with paula.

Besides the organs above, mentioning gerem 'pubic hair' for male or female is also considered taboo in Karo. To avoid this, Karo people call it buk teruh 'bottom hair'. In addition to gerem 'pubic hair', there are several types of hair grow in human body, such as hair grows 
on head which is called buk 'hair', above the eyes is called alis 'eyebrows', on the eyelids is called mbulu mata 'eyelashes', above the mouth is called gumis 'mustache', under the chin is called jenggot 'beard', on the armpit is called mbulu kikik 'armpit hair', and on the legs is called mbulu nahe 'leg feather', and none of these types are considerd taboo.

To mention the activities carried out with the sex organs pesented above are also considered taboo in Karo language such as entek-entek/ngentek 'fuck', merus-merus 'masturbation', and tegir 'erection'. Therefore, these words must also be refined to avoid taboo. The word entek-entek/ngentek 'fuck' can be refined by using the phrase sipanganen 'eating each other'. Sipanganen is intended that man and woman make a love as if they eat each other. Furthermore, merus-merus 'masturbation' is replaced by the word ngelukluki 'curling up', because this act is a sexual stimulus for a man by grasping his dick and sliding his hands in front and back to provide excitement to him and release semen. Furthermore, tegir 'erection' can be refined by the word nggeloh 'life'. Ngggeloh is not considered taboo because it has a general meaning, but if it is associated with sexual activity, the Karo community can understand its connotative meaning, that the word refers to the activity of male genitals.

Words related to human bodily impurities such as ciah 'urine', teges 'semen', kesut 'fart', and tai/ngengek/berak 'shit/feces' also have euphemism forms to avoid mentioning these prohibited words in Karo. In its finer form, ciah is called lau 'water'. The word lau is used to obscure the meaning of urine, so that it can be used in a public conversation. The euphemism form of word teges 'semen' is lau baban dilaki 'man's default water'. This form of paraphrase is considered to be able to shift its taboo meaning to be more subtle. Then, wind released through the rectum is called kesut 'fart', and its form of euphemism is gas 'gas'. The diversion of a special form to the general form makes this word spared from taboo, because gas does not only come from stomach which is released through the rectum but more than that, like natural gas, gas that is released through mouth called belching, and so on. Then, to avoid the taboo of the word tai/ngengek/berak 'shit', Karo people use its euphemism kotoren 'filth'. This word is used to dissimulate its taboo meaning.

An activity to defecate, which in Karo language is called ngengek/ciret/berak 'defecating', is refined with the word ku turai 'to back veranda' or kiduru 'to the vert'. In the past, many Karo people lived in rumah siwaluh jabu (=karo traditional house usually inhabited by $8-10$ families). The siwaluh jabu had a veranda called turai which was usually used as a place where people defecate, and the defecation that fell down would be eaten by pigs. This is the reason why the Karo people used the words ku turai towards such activity. Whereas kiduru 'going to vert' is used because in general the Karo people in the past used to defecate at the edges of the village or bushes. However, the two phrases ku turai and kiduru are almost no longer be used in Karo language, because the existence of the rumah siwaluh jabu is almost extinct. These phrases are gradually replaced by ku belakang 'backward/to the back' or ke kamar mandi 'to the bathroom'.

The urinating activity ciah 'urinate' can also be refined as kiduru, and sometimes they use litap 'wet'. The word litap is used because this activity releases urine which is strongly associated with the wet nature. In addition, urinating is also commonly referred to by the phrase ku kamar mandi or ku belakang as it is explained in previous paragraph. While, taboo words for the activity of removing air through the rectum, namely erkesut 'farting' can be avoided by saying buang gas 'flue gas', because fart is in the form of gas or air coming from the stomach.

In Karo, mentioning parents' names and senior or older relatives' names are considered taboo, and they have no forms of euphemism, that is why Karo culture avoid the 
societies to mention their names. While, the taboo of mentioning specific pronouns engko 'you' with all words related to the pronoun such as entei 'you go there', ariko 'you come here' and possessive adjective $-k o,-m u,-m$ 'your' can be avoided with their polite forms. When someone wants to greet his parents or anchestors or relatives that are older than him/her by using such possessives, she/he is considered breaking the taboo, that is why Karo language has their forms of euphemism or their forms of subtle possessives. The pronoun engko 'you' as subject and object should be changed with kam (=the subtle form of you), entei 'you go there' be changed with tau 'you go there +polite', ariko 'you come here' be changed with mari, and $-k o /-m u /-m$ 'possessive forms of you' be changed with $-n d u$.

However, for the word entei 'you go there', there is a more polite way than the word tau, that is by using the phrase ku jah kam. The words tau and ku jah kam are considered to have slightly different levels of politeness. The word tau is considered a little lower polite because it still contains an element of ordering the interlocutor to leave, while the phrase $k u$ jah kam shows that the interlocutor's departure is on the basis of his/her sincerity to leave, and not on the basis of orders.

\section{Conclusion}

The taboo rules in Karo language have several meanings and functions, all of which lead to noble values which are used as a tool to limit the community in communication so that harmony and good relations can be maintained well. From the research, it can be concluded that the ethnographic methods play comprehensive processes and results in investigating various taboo matters and forms of avoidance that are prevalent and acceptable in accordance with the rules of language and culture. This study finds three types of relationships that are considered taboo to communicate in kinship relationships; various words and phrases classified as context-specific taboo and general taboo in Karo. Then, this study specifically finds various ways and forms of euphemism to avoid these taboos. Kinship taboo can be avoided by strategy of third-person intermediary, strategy of metaphor through object, and strategy of using word 'nina' ('said x'). There are various forms of euphemism used as taboo avoidance of context-specific taboo and general taboo. However, taboo in the form of swearing does not have its form of euphemism because of the purpose and function of this type of taboo as an emotive expression.

\section{References}

Allan, K., \& Burridge, K. (2006). Forbidden Words: Taboo and the Cencoring of Language. New York: Cambridge University Press.

Barus, J., Sibarani, R., Saragih, A., \& ., M. (2018). Linguistic Taboos in Karonese Culture. KnE Social Sciences, 3(4), 411-421. https://doi.org/10.18502/kss.v3i4.1952

Barus, J., Sibarani, R., Saragih, Amrin., \& Mulyadi. (2018). Local Wisdom of Taboos in Karo Language. Language Literacy: Journal of Linguistics, Literature and Language Teaching, 2(2), 94-102, December 2018 e-ISSN: 2580-9962 | p-ISSN: 2580-8672 DOI: https://doi.org/10.30743/II.v2i2.671

Danesi, M. (2004). A Basic Course in Anthropological Linguistics. Toronto: Canadian Scholars' Press Inc.

Duranti, A. (1997). Linguistic Anthropology. New York: Cambridge University Press.

Foley, W. A. (1997). Anthropological Linguistics: An Introduction. Oxford: Blackwell.

Hymes, D. (1963). Language in Culture and Society. A Reader in Linguistics and Anthropology. New York: Harper \& Row Publisher. 
Sembiring, M. (2013). Translating Rebu in Karonese Society into English. IOSR Journal of Humanities and Social Science (IOSR-JHSS), 17.(1), 30-36. Retrived from http://www.iosrjournals.org.

Spradley, J.P. (1979). The Ethnographic Interview. USA: Hartcourt Brace Jovanovich College Publishers.

Wardhaugh, Ronald. (2010). An Introduction to Sociolinguistics. $6^{\text {th }}$ Edition. United Kingdom: Wiley-Blackwell. 